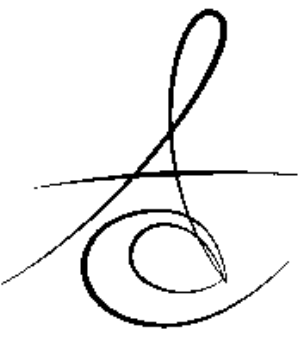

\section{DİŞ HEKİMLİĞİ FAKÜLTESİ PREKLİNİK VE KLİNİK ÖĞRENCİLERİNİN DENTAL KAYGI VE KORKU DÜZEYLERİNİN DEĞERLENDİRİLMESİ ${ }^{*}$}

\author{
THE EVALUATION OF DENTAL FEAR AND ANXIETY LEVELS OF PRECLINICAL \\ AND CLINICAL DENTAL STUDENTS ${ }^{*}$
}

\author{
Dr. Dt. Burçin ACAR** \\ Prof. Dr. Saim YOLOĞLU ${ }^{* * * *}$
}

Makale Kodu/Article code: 2989

Makale Gönderilme tarihi: 11.08 .2016

Kabul Tarihi; 07.12 .2016

\section{öz}

Amaç: Diş tedavisi ile ilgili kaygı ve korku birçok hasta için sorundur ve bu durum tedavi için engel oluşturabilir. Bazı hastalar korkuları nedeniyle diş hekiminden kaçınırlar. Bu çalışmanın amacı preklinik öncesi $(1,2,3$. sınıf) ve klinik öğrencileri (4, 5. sınıf) arasındaki dental anksiyeteyi değerlendirmektir.

Gereç ve Yöntem: Bu çalışmaya İnönü Üniversitesi Diş Hekimliği Fakültesi' nde eğitim gören 227 öğrenci (118 kız,109 erkek) katıldı. Öğrencilere anket formları verilerek, soruları yanıtlamaları istendi. Öğrencilerin dental anksiyete düzeyini belirlemek için Corah'ın dental anksiyete skalası ve Dental Korku Skalası kullanıldı.

Bulgular: Bu çalışmanın sonuçları göstermiştir ki preklinik öğrencilerinde Corah'ın dental anksiyete skalası' na göre ortalama skor $(8,69)$, klinik öğrencilerinden $(7,61)$ yüksektir. Ancak grupların ortalaması arasındaki fark istatistiksel olarak anlamlı değildir. Dental Korku Skalası puanlarına göre 1(randevu alma), 2 (randevu iptal) ve 12. (muayenehane kokusu) sorular haricindeki sorulara verilen cevaplar arasında istatistiksel olarak anlamlı fark bulunmuştur. En yaygın fizyolojik tepki preklinik $(2,25 \pm 0,85)$ ve klinik öğrencileri $(1,89 \pm 0,81)$ için de kasların gerginliğidir. Lokal anestezi enjeksiyonu iki grup için de en çok korkulan diş tedavi prosedürü olmuştur. $(p<0,05)$

Sonuç: Yaptığımız çalışmada klinik ve preklinik öğrencileri arasında dental anksiyete açısından anlamlı bir fark görülmemiştir. Ancak preklinik sınıflarında anksiyete derecesinin daha yüksek olduğu saptanmıştır. Bu durumun preklinik öğrencilerinin diş hekimliği konusunda daha az bilgiye ve pratiğe sahip olmasından kaynaklandığını düşünebiliriz.

Anahtar kelimeler: Dental anksiyete, Diş hekimliği öğrencileri, Diş hekimi korkusu, DAS, DKS

\section{ABSTRACT}

Aim: Fear and anxiety about dental treatment is a problem for many patients and this can be a barrier to treatment. Some patients avoid from dentists because of their fears. The aim of this study was to evaluate the dental anxiety between the preclinical $\left(1^{\text {st }}, 2^{\text {nd }}, 3^{\text {rd }}\right.$ class $)$ and clinical $\left(4^{\text {th }}, 5^{\text {th }}\right.$ class $)$ dental students.

Material and Methods: 227 students of Inonu University Faculty of Dentistry were (109 male, 118 female) participated in this study. Questionnaire forms were given to the students for answer the questions. To determine the dental anxiety levels of students Corah's dental anxiety scale and a Dental Fear Survey was used.

Results: The results of this study indicated that Corah's dental anxiety scale score of preclinical students(8.69) was higher than clinical students(7.61). But there was no statistically significant differences between the scores of groups. According to the Dental Fear Survey scores, statistically significant differences were found in questions, except the questions 1 (making an appointment), 2(cancel an appointment) and 12(smell of the dentist's office). The most common physiological response was the tension of the muscles for preclinical $(2.25 \pm 0.85)$ and clinical $(1.89 \pm 0.81)$ students. Local anesthesia injection was the most fearful dental procedure for two groups. $(p<0.05)$

Conclusion: In this study, the analysis have revealed that there were no significant differences between the clinical and preclinical students. But, it was determined that preclinical dental students were higher degree of anxiety. We think of due to the fact that preclinical students receive less training and less detailed information about dental practices.

Key words: Dental anxiety, Dental students, Dental fear, DAS, DFS

*Erciyes Üniversitesi Diş Hekimliği Fakültesi Pedodonti Anabilim Dalı

** Özel Konyaaltı Antera Ağız Diş Sağlığı Polikliniği

*** İnönü Üniversitesi Diş Hekimliği Fakültesi Pedodonti Anabilim Dalı

**** İnönü Üniversitesi Tıp Fakültesi Biyoistatistik ve Tıp Bilişimi Anabilim Dalı

₹Bu çalışma 12-15 Mayıs 2016 tarihleri arasında Banja Luka/ Bosna Hersek'te düzenlenen 21. BaSS

(Balkan Stomatology Society) kongresinde poster sunumu olarak teblig edilmiştir 


\section{GİRİş}

Sıklıkla birbirleri yerine kullanılabilen korku ve kaygı farklı iki kavramdır. Psikiyatristlere göre korku; tanımlanabilen ve sebebi dışarıda bulunan bir tehdide karşı gösterilen bir tepkidir. Anksiyete ise, içten gelen, belirsiz ya da sebebi iç çatışmaya dayalı olan bir tehdide karşı gösterilen bir tepkidir ${ }^{1}$. Dental anksiyete; hastanın diş hekimine gittiğinde ya da sadece diş hekimi koltuğuna tedavi beklentisiyle oturduğu anda oluşan bir anksiyete formudur ${ }^{1}$. Bazı araştırmacılar tarafından kabul edilen görüş; bu anksiyete şeklinin kişilik özellikleriyle bağlantılı olduğu ve diğer anksiyetelerle ilişkili olmadığı yönündedir ${ }^{2}$. Ayrıca çocukluktan kaynak alan dental anksiyete, yetişkinlikte oluşan dental anksiyeteden daha ağır seyretmektedir. Özellikle diş çekimi ve dolgu gibi invaziv işlemlerde daha çok tetiklendiği görülmüştür ${ }^{3,4}$.

Diş hekimliği kaygı-korkusuyla; yaş, cinsiyet, planlanan tedavi işleminin özellikleri, eğitim düzeyi gibi birçok faktör ilişkilidir ${ }^{5}$. Düşük eğitim düzeyinin de, yüksek kaygı seviyesini beraberinde getirdiği bilidirilmektedir ${ }^{6,7}$.

Diş hekimliği konusunda alınan eğitim dental kaygı seviyesini etkileyebilir. Çalışmamızın amacı henüz klinik uygulamalara geçmemiş, diş hekimliği konusunda yeterli bilgi birikimine sahip olmayan diş hekimliği fakültesi 1., 2. ve 3. sınıf öğrencileri (preklinik) $(n=183)$ ve diş tedavilerini uygulamaya başlamış 4.ve 5.sınıf öğrencileri (klinik) $\quad(n=54)$ arasındaki dental kaygı düzeyini karşılaştırmalı olarak incelemektir.

\section{MATERYAL VE METOD}

Çalışmamıza İnönü Üniversitesi Diş hekimliği Fakültesi' nde eğitim alan 227 öğrenci katıldı. Preklinik ve klinik öğrencilerine birer anket formu verilerek, soruları yanıtlamaları istendi. Öğrencilerin dental anksiyete düzeyini belirlemek için güvenirliliği ve geçerliliği kanıtlanmış olan Corah'ın dental anksiyete skalası(DAS) (Şekil 1) ve yetişkinlerde dental kaygı ve korku düzeyinin belirlenmesinde en sık kullanılan ölçeklerden biri olan Dental Korku Skalası (DKS) (Şekil 2) kullanıldı.

Kullanılan DAS skalasında dört soru ve her soru için beş cevap seçeneği bulunmaktadır. Anksiyete düzeyi (a) seçeneğine 1 , (b) seçeneğine 2 , (c) seçeneğine 3 , (d) seçeneğine 4 ve sonuncuya (e) 5 puan verilerek hesaplandı. Bu testin skorları minimum
4, maksimum 20 puan arasında değişmektedir. Sonucun 13-14 arasında olması durumunda kişide anksiyete olduğundan şüphelenilir. 15 puan ve üstü $(\geq 15)$ değerlerde anksiyete kesinlik kazanmaktadır. 13'den az puan düşük derecede, 13-14 orta derecede, 15 ve yukarısı ise yüksek derecede anksiyeteyi ifade eder. Uygulanan ankete ait sorular Şekil-1'de gösterilmiştir.

Lütfen aşağıda soruları cevaplayınız.

Adı Soyadı:

Cinsiyet: $E($ ) $K($ )

Yaşı:

Sınıfi:

1)Yarın diş hekimine gidecek olsanız kendinizi nasıl hissedersiniz?

a)Eğlenceli bir deneyim olacağını düşünürüm

b)Bu durumu önemsemem ve hiç endişe etmem.

c)Çok az huzursuzluk duyarım.

d)Hoş olmayan ve ağrılı bir olay olacağını düşündüğüm için korkarım.

e)Diş hekimi ne yapacak diye korkarım

2)Diş hekimi muayenehanedesiniz ve sıranın size gelmesini bekliyorsunuz kendinizi nasıl hissedersiniz?

a)Rahat hissederim

b)Biraz huzursuz hissederim

c)Gergin hissederim

d)Endişeli ve sıkıntılı hissederim.

e)Çok korkarım, vücudumda terleme ve bulantı gibi değişiklikler hissederim.

3)Diş hekimi koltuğuna oturdunuz ve doktorunuzun tedavi için aletlerini hazırlamsını bekliyorsunuz. Kendinizi nasıl hissedersiniz?

a)Rahat hissederim

b)Biraz huzursuz hissederim

c)Gergin hissederim

d)Endişeli ve sıkıntılı hissederim.

e)Çok korkarım, vücudumda terleme ve bulantı gibi değişiklikler hissederim.

4)Diş hekiminin koltuğuna oturdunuz ve doktorunuz dişlerinizi temizlerken kendinizi nasıl hissedersinzi?

a)Rahat hissederim

b)Biraz huzursuz hissederim

c)Gergin hissederim

d)Endişeli ve sıkıntılı hissederim.

e)Çok korkarım,vücudumda terleme ve bulantı gibi değişiklikler hissederim

Şekil 1. Corah' ın Dental Anksiyete Skalası (DAS) 
Lütfen aşağıdaki sorulara sizin için uygun olan seçeneği işaretleyiniz. 1-Diş hekimi korkusu hiç randevu almamanıza/ertelemenize sebep oldu mu?

a-Hiç b-Bir veya İki defa c-Birkaç defa d-Sık sık e-Neredeyse her zaman

2-Diş hekimi korkusu nedeniyle hiç randevunuzu iptal ettiğiniz ya da gitmediğiniz oldu mu?

a-Hiç b-Bir veya İki defa c-Birkaç defa d-Sık sık e-Neredeyse her zaman

3-Diş tedavim yapılırken kaslarım gerilir.

a-Neredeyse hiç b-Çok az c-Biraz d-Çok e-Çok fazla

4-Diş tedavim yapılırken nefes alış-veriş oranım artar.

a-Neredeyse hiç b-Çok az c-Biraz d-Çok e-Çok fazla

5-Diş tedavim yapılırken terlerim.

a-Neredeyse hiç b-Çok az c-Biraz d-Çok e-Çok fazla

6-Diş tedavim yapııırken midemde bulantı ve karın ağrısı hissederim.

a-Neredeyse hiç b-Çok az c-Biraz d-Çok e-Çok fazla

7-Diş tedavim yapııırken kalp atış hızım artar.

a-Neredeyse hiç b-Çok az c-Biraz d-Çok e-Çok fazla

8-Diş hekiminden randevu alırken korku, gerginlik duyarım.

a-Neredeyse hiç b-Çok az c-Biraz d-Çok e-Çok fazla

9-Diş hekiminin muayenehanesine yaklaşırken korku, gerginlik duyarım.

a-Neredeyse hiç b-Çok az c-Biraz d-Çok e-Çok fazla

10-Bekleme odasında otururken korku, gerginlik duyarım.

a-Neredeyse hiç b-Çok az c-Biraz d-Çok e-Çok fazla

11-Diş hekimi koltuğunda (ünitinde) otururken korku, gerginlik duyarım.

a-Neredeyse hiç b-Çok az c-Biraz d-Çok e-Çok fazla

12-Muayene odasının kokusunu aldığımda korku, gerginlik duyarım.

a-Neredeyse hiç b-Çok az c-Biraz d-Çok e-Çok fazla

13-Diş hekimini içeriye girerken gördüğümde korku, gerginlik duyarım.

a-Neredeyse hiç b-Çok az c-Biraz d-Çok e-Çok fazla

14-Anestezi iğnesini gördüğümde korku-gerginlik duyarım.

a-Neredeyse hiç b-Çok az c-Biraz d-Çok e-Çok fazla

15-Anestezi iğnesini hissederken korku, gerginlik duyarım.

a-Neredeyse hiç b-Çok az c-Biraz d-Çok e-Çok fazla

16-Aeretörü (dönen aletleri) gördüğümde korku, gerginlik duyarım.

a-Neredeyse hiç b-Çok az c-Biraz d-Çok e-Çok fazla

17- Aeretör (dönen aletleri) sesi duyduğumda korku, gerginlik duyarım.

a-Neredeyse hiç b-Çok az c-Biraz d-Çok e-Çok fazla

18- Aeretörün (dönen aletlerin) dönme titreşimini hissettiğimde korku, gerginlik duyarım.

a-Neredeyse hiç b-Çok az c-Biraz d-Çok e-Çok fazla

19-Diş hekimi tarafından dişlerim temizlendiğinde korku, gerginlik duyarım.

a-Neredeyse hiç b-Çok az c-Biraz d-Çok e-Çok fazla

Şekil 2. Dental Korku Skalası (DKS)
1973 yilında Kleinknecht ve arkadaşları ${ }^{8}$ tarafindan ilk defa uygulanan Dental Korku Skalası 19 soru içermekte, sorulara verilen yanıtlar 1-5 arası puanlandırımaktadır. DKS diş hekimine ve diş hekimliği uygulamalarına duyulan korku düzeyini belirlemeyi amaçlamaktadır. DKS, diş hekimine gitmekten kaçınma, korkunun insan vücudundaki belirtileri ve diş hekimliği pratiğindeki çeşitli uygulamalara karşı duyulan korku düzeyini gösteren bir skaladır ${ }^{8}$. Bu skalaya ait sorular Şekil 2'de gösterilmiştir:

Anket formlarının doldurulduktan sonraki aşamasında elde edilen veriler, SPSS-15 veri programına (Statistical Package for Social Science-SPSS Inc., Chicago, IL, ABD) aktarılarak tek yönlü varyans analizi (one-way ANOVA) ve non-parametrik testlerden Mann Whitney-U testlerinden yararlanılarak istatistiksel analizleri gerçekleştirildi.

\section{BULGULAR}

Çalışmaya katılan 227 öğrencinin 118'i kız (\%52), 109 'u erkekti (\%48). Cinsiyet açısından preklinik (\%48, 1 erkek, \%51,9 klz) ve klinik öğrencileri (\%47,7 erkek, \%52,3 kız) arasında istatistiksel olarak anlamlı bir fark bulunmamıştır $(p>0,05)$.

Preklinik ve klinik öğrencilerinin yaş ortalaması karşılaştıııldığında ise; preklinik $(20,42 \pm 1,35)$ ve klinik $(23,22 \pm 1,05)$ öğrencileri arasında istatistiksel olarak anlamlı fark olduğu görülmüştür $(p<0,05)$.

Öğrencilere "yarın diş hekimine gidecek olsanız kendinizi nasıl hissedersiniz" sorusu sorulduğunda preklinik öğrencileri en çok $(\% 44,8)$ "çok az huzursuzluk hissederim" cevabını verirken, klinik öğrencileri ise en fazla(\%52,3) "çok az huzursuzluk hissederim" cevabını vermiştir.

Preklinik öğrencileri "diş hekimi muayenehanesindesiniz ve sıranın size gelmesini bekliyorsunuz kendinizi nasll hissedersiniz" sorusuna $\% 42,1^{\prime} i$ kendilerini biraz husursuz hissedeceklerini ifade ederken, klinik öğrencilerinin \%43,2' si kendilerini rahat hissedeceğini ifade etmiştir. Ancak iki grup arasında istatistiksel olarak anlamlı bir fark bulunmamışıı $(p>0,05)$.

Öğrencilere "diş hekimi koltuğuna oturdunuz ve doktorunuzun tedavi için aletlerini hazırlamasını bekliyorsunuz kendinizi nasıl hissedersiniz?" diye sorulduğunda preklinik öğrencilerinin $\% 38,8$ 'i "biraz huzursuz hissederim", klinik öğrencileri ise $\% 45,5$ rahat hissederim" demiştir. Bu soruya verilen cevaplar karşılaş- 
tırıldığında istatistiksel olarak anlamlı bir fark bulunmamıştır ( $p>0,05)$.

Son soruya (diş hekiminin koltuğuna oturdunuz ve doktorunuz dişlerinizi temizlerken kendinizi nasıl hissedersiniz) ise preklinik öğrencileri en fazla $(\% 45,4)$ "biraz huzursuz hissederim" cevabını verirken, klinik öğrencileri en fazla $(\% 52,3)$ "rahat hissederim" cevabını vermiştir. Bu soruya verilen yanıtlar açısından gruplar arasında da istatistiksel olarak anlamlı bir fark bulunmamıştır ( $p>0,05)$.

Çalışmamızda, 227 öğrenciden preklinik' de 35 $(\% 19,12)$, klinik sınıflarda $(\% 5,55)$ ise 3 kişide DAS puanı $\geq 15$ (yüksek derecede anksiyete) olarak bulunmuştur (Grafik 1). Anket puanlamasında preklinik' de DAS ortalaması 8,69 iken, klinik sınıflarda 7,61'dir. Preklinik ve klinik öğrencilerinde "az düşük" derecede anksiyete saptanmıştır. Preklinik öğrencilerinde anksiyete seviyesi daha yüksek olsa da klinik öğrencileri ile aralarında anlamlı bir fark elde edilmemiştir ( $p>0,05)$.

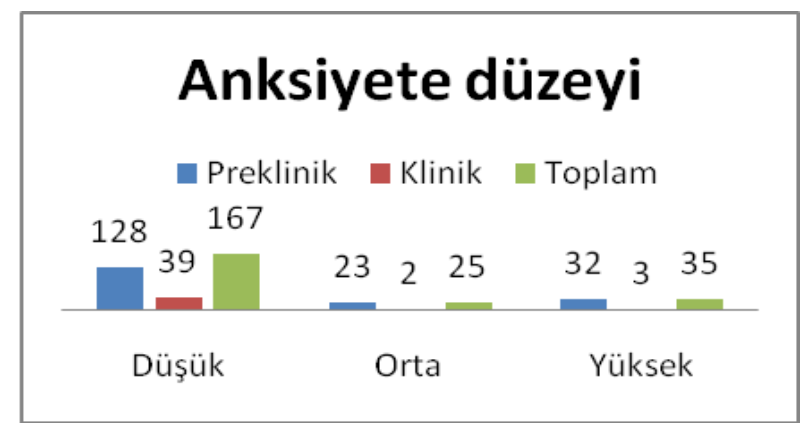

Grafik 1. Sınıflara göre Dental Anksiyete Skala (DAS) Skor Grafiği

Çalışmamızın DKS puanlarına göre diş hekiminden korku nedeni ile randevu almama veya randevuya gitmeme durumları açısından 2 grup arasında istatistiksel olarak anlamlı bir fark bulunmamıştır $(p>0,05)$.

DKS verilerindeki kişinin tedavi esnasındaki hislerini sorgulayan; nefes alış-veriş oranında artma, terleme, bulantı ve karın ağrısı bulguları arasında 2 grup arasında fark tespit edilmiştir $(p<0,05$.) Tedavi için randevu alınmasından diş hekimi ile karşılaşılana kadarki dönem değerlendirildiğinde (soru 8-19) korku ve gerginlik duyma oranları (12.soru muayenehane kokusu hariç) iki grup için farklılık göstermiştir (Tablo 1) $(p<0,05)$.

Çalışmamızda DAS içerisindeki verilerden lokal anestezi enjeksiyonuna her iki grubun yanıtları ista- tistiksel olarak anlamlı seviyede yüksek dental kaygı ile ilişkili bulunurken, katılan öğrencilerin DKS verileri değerlendirildiğinde; muayene odasına girildiğinde korku ve gerginlik duyma, aeretorü görme, diş temizliği işlemi, aeretorün sesini duyma, anestezi iğnesini görmeye ilişkin korku/gerginlik düzeyleri ve diş tedavisi yapılırken kalp atış hızı artması, terleme, bulantı ve kasların gerilme hissi istatistiksel olarak anlamlı ölçüde yüksek korku ile ilişkili bulunmuştur $(p<0,05)$.

Çalışmamızın DKS puanlarına göre en yaygın fizyolojik tepki preklinik $(2,25 \pm 0,85)$ ve klinik öğrencileri $(1,89 \pm 0,81)$ için kasların gerginliği olurken, lokal anestezi enjeksiyonu her iki grupta da en korkulan diş hekimliği uygulaması olmuştur.

Tablo 1. Sinıflara göre Dental Korku Skala (DKS) Skor Tablosu

\begin{tabular}{|c|c|c|c|c|c|}
\hline & \multicolumn{2}{|c|}{ Preklinik } & \multicolumn{2}{|c|}{ Klinik } & \multirow[t]{2}{*}{$\mathbf{p}$} \\
\hline & $\mathbf{n}$ & $\begin{array}{l}\text { Ortalama- } \\
\text { S.S. }\end{array}$ & $\mathbf{n}$ & $\begin{array}{l}\text { Ortalama- } \\
\text { S.S. }\end{array}$ & \\
\hline Randevu & 183 & $1,40 \pm 0,654$ & 44 & $1,23 \pm 0,565$ & 0,77 \\
\hline İptal & 183 & $1,16 \pm 0,413$ & 44 & $1,09 \pm 0,291$ & 0,315 \\
\hline Kas Gerilmesi & 183 & $2,25 \pm 0,851$ & 44 & $1,89 \pm 0,813$ & $* 0,012$ \\
\hline Nefes & 183 & $2,13 \pm 0,877$ & 44 & $1,75 \pm 0,751$ & $* 0,008$ \\
\hline Terleme & 183 & $1,83 \pm 0,840$ & 44 & $1,52 \pm 0,731$ & $* 0,027$ \\
\hline $\begin{array}{l}\text { Mide } \\
\text { Bulantısı }\end{array}$ & 183 & $1,63 \pm 0,841$ & 44 & $1,36 \pm 0,685$ & $* 0,046$ \\
\hline $\begin{array}{l}\text { Kalp } \\
\text { Çarpıntısı }\end{array}$ & 183 & $2,04 \pm 0,860$ & 44 & $1,52 \pm 0,698$ & $* 0,000$ \\
\hline Korku & 183 & $1,77 \pm 0,940$ & 44 & $1,39 \pm 0,579$ & $* 0,02$ \\
\hline Muayenehane & 183 & $1,89 \pm 0,910$ & 44 & $1,50 \pm 0,699$ & $* 0,008$ \\
\hline $\begin{array}{l}\text { Bekleme } \\
\text { Odası }\end{array}$ & 183 & $1,92 \pm 0,874$ & 44 & $1,57 \pm 0,625$ & $* 0,017$ \\
\hline Ünit & 183 & $2,08 \pm 0,931$ & 44 & $1,70 \pm 0,765$ & $* 0,014$ \\
\hline Koku & 183 & $1,89 \pm 0,968$ & 44 & $1,55 \pm 0,663$ & 0,054 \\
\hline $\begin{array}{l}\text { Diş Hekimini } \\
\text { Görme }\end{array}$ & 183 & $1,77 \pm 0,861$ & 44 & $1,45 \pm 0,627$ & $* 0,037$ \\
\hline İğneyi Görme & 183 & $2,44 \pm 1,057$ & 44 & $1,93 \pm 0,998$ & $* 0,003$ \\
\hline $\begin{array}{l}\text { İğneyi } \\
\text { Hissetme }\end{array}$ & 183 & $2,60 \pm 1,021$ & 44 & $2,07 \pm 0,950$ & $* 0,001$ \\
\hline $\begin{array}{l}\text { Aeretoru } \\
\text { Görme }\end{array}$ & 183 & $2,04 \pm 1,037$ & 44 & $1,39 \pm 0,538$ & $* 0,000$ \\
\hline $\begin{array}{l}\text { Aeretoru } \\
\text { Duyma }\end{array}$ & 183 & $2,09 \pm 1,078$ & 44 & $1,39 \pm 0,618$ & $* 0,000$ \\
\hline $\begin{array}{l}\text { Aeretorun } \\
\text { Titreşimi }\end{array}$ & 183 & $2,27 \pm 1,138$ & 44 & $1,57 \pm 0,625$ & $* 0,000$ \\
\hline Diş Temizliği & 183 & $1,90 \pm 0,967$ & 44 & $1,43 \pm 0,967$ & $* 0,004$ \\
\hline
\end{tabular}

\section{TARTIŞMA}

Dental anksiyete, diş hekimliğindeki modern gelişmelere karşın, halen birçok ülkede ve toplu- 
mumuzda, hekim ve hasta açısından sorun oluşturabilen yaygın bir durumdur. ${ }^{9,10} \mathrm{Bu}$ çalışmada diş hekimliği eğitiminin dental anksiyete üzerine etkisinin olabileceği düşüncesiyle, diş hekimliği fakültesi preklinik ve klinik öğrencilerinin dental anksiyete düzeyleri ve anksiyete ile ilişkili faktörler araştırılmıştır.

Corah' in dental anksiyete skalası ve dental korku skalası, dental anksiyete düzeyinin belirlenmesinde geçerli ve güvenilir ölçeklerdir. ${ }^{11}$ Newton ve Buck'ın 2000 yılında yayınladıkları derlemede dental anksiyetenin değerlendirilmesi ve bu konuda kullanılan ölçeklerin güvenilirliği araştırımış Corah'ın Dental Anksiyete Ölçeği'nin en yaygın kullanılan ölçüt olduğu belirtilmiştir ${ }^{12}$. Şeydaoğlu ve arkadaşlarının yapmış olduğu çalışmada DAS'ın Türkçe uyarlamasının her yaş grubunda kullanılabilecek geçerli ve güvenilir bir skala olduğu gösterilmiştir. ${ }^{13}$ DKS' $^{\prime}$ nin de Türk popülasyonunda da geçerli ve güvenilir olduğu yapılan bir çalışmada da gösterilmiştir. ${ }^{14} \mathrm{Bu}$ nedenle çalışmamızda dental anksiyete seviyeleri her 2 skala kullanılarak araştırılmıştır.

Yüzügüllü ve arkadaşları yaptıkları çalışmada istatistiksel olarak fark bulunmasa da bayanlarda anksiyete düzeyinin erkeklere oranla yüksek olduğunu tespit etmiştir. ${ }^{15}$

Anksiyete seviyesinin konservatif tedavi esnasında yaş, cinsiyet ve eğitim durumu ile ilişkisinin incelenmesinin amaçlandığı bir diğer çalışmada, yaş ve eğitim durumu ile anksiyete arasında DAS ve DKS skorlarına göre bir ilişki saptanmamış; ancak kadın katılımcıların anksiyete seviyelerinin anlamlı derecede yüksek izlendiği bildirilmiştir. ${ }^{16}$

Çalışmamız sonuçlarına göre kız ve erkeklerdeki anksiyete düzeyi arasında istatistiksel olarak bir farklılık görülmemiştir $(p>0,05)$. Çağırankaya ve Kansu'nun diş hekimliği öğrencileri üzerinde yaptıkları çalışma da, çalışmamızı destekler niteliktedir. ${ }^{17}$

Amerika Birleşik Devletleri'nde (ABD) yapılan çalışmalarda elde edilen verilerin tüm nüfusa yansıtılmasıyla yaklaşık 45 milyon kişinin diş hekimliğine yönelik yüksek anksiyete seviyesine sahip olduğu, 23 milyon kişinin anksiyete nedeniyle diş hekimliği uygulamalarına başvurmak istemediği sonucuna varılmıştır ${ }^{12}$. Kanada'da gerçekleştirilen bir çalışmada ise periodontal cerrahi, diş çekimi ve endodonti uygulamaları gibi tedavi işlemlerinin invazivliğinin arttığı durumlarda hastaların sedasyon veya genel anesteziye gereksinim gösterdikleri ve popülasyonun $\% 5,5^{\prime}$ inin diş hekimliği prosedürlerinden ötürü yüksek anksiyete düzeyine sahip olduğu rapor edilmiştir. ${ }^{18}$ Türkiye'de Modifiye Dental Anksiyete Skalası kullanılarak gerçekleştirilen bir çalışmada dental anksiyete oranı \%8,8 olarak bildirilmiştir. ${ }^{19}$ Samur-Ergüven ve arkadaşlarının diş hekimliği fakültesi ağız, diş ve çene cerrahisi kliniğine başvuran hastalar üzerinde yaptıkları bir çalışmada hastaların yaklaşık $1 / 7$ 'sinin yüksek dental anksiyete düzeyine sahip olduğu saptanmıştır. ${ }^{20}$ Ayrıca düşük eğitim düzeyinin, daha yüksek anksiyete seviyesi ile ilişkili olduğunu bildiren çalışmalar da mevcuttur. ${ }^{6,7}$ Acharya 482 diş hekimliği öğrencisi üzerinde yapmış olduğu çalışmada eğitim seviyesi düşük olan grupta anksiyete düzeyinin anlamlı derecede yüksek olduğunu göstermiştir. ${ }^{10}$ Ayrıca diş hekimliği deneyimi az olan grupta dental anksiyete düzeyinin ve diş hekimliğine dair olumsuz düşüncelerin daha fazla olduğu rapor edilmiştir. ${ }^{10}$ Çalışmamızda preklinik öğrencilerinde yüksek derecede anksiyete görülme durumu (DAS puanı $\geq 15$ ) daha fazla bulunmuştur. Samur-Ergüven ve arkadaşlarının diş hekimliği fakültesi birinci sınıf öğrencileri ile son sınıf öğrencilerinin dental anksiyete düzeylerini karşılaştırmalı olarak değerlendirdikleri çalışmada, dental anksiyeteye sahip olan öğrenci oranını 1. sınıf öğrencilerinde $\% 10,4,5$. sınıf öğrencilerinde ise \%1,8 olarak bildirmiştir. ${ }^{21} \mathrm{Bu}$ durum dental anksiyetenin azalmasında diş hekimliği eğitimin katkısı olabileceğini desteklemektedir.

Dental tedavi işlemleri sırasında hastaların dental anksiyete düzeylerine bağlı olarak pek çok sistemik belirtiler ortaya çıkabilir. ${ }^{22}$ Bodrumlu ve arkadaşlarının yaptığı çalışmada bireylerde en fazla oluşan sistemik belirtiler; kasların kasılması, kalbin hızlı çarpması ve hızlı nefes alıp verilmesidir ${ }^{23}$. Çalışmamızda da "diş tedavim yapılırken kaslarım gerilir, kalp atış hızım artar ve tedavim yapılırken korku ve gerginlik duyarım" gibi cevaplar benzer sistemik etkileri göstermektedir.

Bellini ve arkadaşları diş hekimine gidildiğinde en fazla korkuya neden olan durumun ağrı duyma $(\% 48,8)$ ve enjeksiyon $(\% 29,9)$ olduğunu belirtmişlerdir ${ }^{9}$. Pek çok çalışmada da dental işlemler sırasında en fazla korkuya neden olan durumun lokal enjeksiyon olduğu gösterilmiştir. ${ }^{8,24-27}$ Çalışmamızda da en fazla korkuya neden olan dental girişim lokal enjeksiyon olarak belirlenmiştir.

Yapılan çalışmalarda diş hekimliği öğrencileri ile aynı yaş gruplarında ancak farklı bölümlerde okuyan (tıp ve mühendislik) öğrencilerin dental kaygı düzeyleri 
kıyaslanmış ve diş hekimliği eğitimi gören öğrencilerin daha az dental kaygıya sahip oldukları ancak bu farkın anlamlı olmadığı görülmüştür. ${ }^{28,29}$ Bu çalışma diş hekimliği hakkında az bilgi birikimi olsa dahi anksiyeteyi etkileyebileceğini göstermesi açısından önemlidir. Çaışmamızda diş hekimliği klinik öğrencilerinde lokal enjeksiyon, aeretor sesi ve titreşimi, dişlerin temizlenmesi gibi tedavi prosedürlerindeki korkuların eğitimle azaldığı görülmüştür.

\section{SONUÇ}

Yaptığımız çalışmada klinik ve preklinik öğrencileri arasında dental anksiyete açısından anlamlı bir fark görülmemiş ancak preklinik sınıflarında anksiyete derecesinin daha yüksek olduğu belirlenmiştir. Sonuç olarak, eğitimin dental kaygı ve korku düzeyiyle ilişkili olduğu ve diş hekimliği eğitimi alan ve uygulamalar hakkında bilgi sahibi olan öğrencilerin daha az dental anksiyete duyduğunu düşünmekteyiz.

Esra Kızılcı: ORCID ID: 0000- 0003-0746-7087

Burçin Acar: ORCID ID: 0000-0002-0992-0140

Zekiye Şeyma Sizer: ORCID ID: 0000-0002-6744-7830

Saim Yoloğlu: ORCID ID: 0000-0002-9619-3462

\section{KAYNAKLAR}

1. Weiner AA. The fearful dental patient: A guide to understanding and managing. 1st ed. Oxford; Wiley-Blackwell: 2011.p.16-35.

2. Fuentes D, Gorenstein C, Hu LW. Dental anxiety and trait anxiety: an investigation of their relationship. Br Dent J 2009; 206: 17.

3. Locker D, Liddell A. Correlates of dental anxiety among older adults. J Dent Res 1991; 70: 198203.

4. Weiner AA, Sheehan DV. Etiology of dental anxiety: psychological trauma or CNS chemical imbalance?. Gen Dent 1990; 38: 39-43.

5. Marakoğlu İ, Demirer AGS, Özdemir UPD, Sezer $H$. Periodontal tedavi öncesi durumluk ve süreklik kaygi düzeyi. CÜ Diş Hek Fak Derg 2003; 6: 74-9.

6. Erten $\mathrm{H}$, Akarslan ZZ, Bodrumlu E. Dental fear and anxiety levels of patients attending a dental clinic. Quintessence Int 2006; 37: 304-10.

7. Rose RW, Vorobyeva AG, Skipworth JD, Nicolas E, Rall GF. Altered levels of STAT1 and STAT3 influence the neuronal response to interferon gamma. J Neuroimmunol 2007; 192: 145-56.
8.

9. Kleinknecht RA, Klepac RK, Alexander LD. Origins and characteristics of fear of dentistry. J Am Dent Assoc 1973; 86: 842-8.

10. Bellini M, Maltoni O, Gatto M, Pelliccioni G, Checchi V, Checchi L. Dental phobia in dentistry patients. Minerva Stomatol 2008; 57: 485-95.

11. Acharya S. Factors affecting dental anxiety and beliefs in an Indian population. J Oral Rehabil 2008; 35: 259-67.

12. Corah NL. Development of a dental anxiety scale. J Dent Res 1969; 48: 596.

13. Newton JT, Buck DJ. Anxiety and pain measures in dentistry: a guide to their quality and application. J Am Dent Assoc 2000; 131: 144957.

14. Seydaoğlu G, Doğan $M C$, Uğuz Ş, Yazgan Inanç $B$, Çelik M. corah dental anksiyete skalasının türkçe uyarlamasının geçerlilik-güvenilirliği ve dental anksiyete görülme sıklığı. OMÜ Diş Hek Fak Derg 2006; 7: 7-14.

15. Firat $D$, Tunc $E$, Sar V. Dental anxiety among adults in Turkey. J Contemp Dent Pract 2006; 7: 75-82.

16. Yüzügüllü $B$, Gülşahı $A$, Çelik $C$, Bulut Ş. Klinik öncesi diş hekimliği öğrencilerinin dental anksiyete düzeylerinin belirlenmesi. OndokıIz Mayıs Univ Diş Hek Fak Derg 2009; 10: 106-10.

17. Zorba DYO, Yıldız M, Turgut DH, Bayındır YZ. Konservatif tedavi esnasinda anksiyetenin yaş, cinsiyet ve eğitim durumu bakımından incelenmesi. Atatürk Üniv Diş Hek Fak Derg 2004; 14: 35-40.

18. Çağırankaya L, Kansu Ö. Dişhekimliği öğrencilerinde dental anksiyetenin sebep ve sonuçları. Hacettepe Diş Hek Fak Derg 2005; 29: 8-11.

19. Chanpong B, Haas DA, Locker D. Need and demand for sedation or general anesthesia in dentistry: a national survey of the Canadian population. Anesth Prog 2005; 52: 3-11.

20. İlgüy $D$, İlgüy $M$, Dinçer $S$, Bayirli G. Reliability and validity of the Modified Dental Anxiety Scale in Turkish patients. J Int Med Res 2005; 33: 2529. 
21. Ergüven Samur S, Kılınç Y, Delilbaşı E, Işık B. Bir diş hekimliği fakültesi ağız, diş ve çene cerrahisi kliniğine başvuran hastaların dental kaygı düzeylerinin değerlendirilmesi. Acta Odontol Turc 2015; 32: 7-11.

22. Ergüven Samur S, Işık B, Kılınç $Y$. Diş hekimliği fakültesi birinci sınıf öğrencileri ile son sınıf öğrencilerinin dental kaygı-korku düzeylerinin karşılaştırmalı olarak değerlendirilmesi. Acta Odontol Turc 2013; 30: 70-6.

23. Sodeman WA, Sodeman TM. Pathologic physiology mechanisms of disease. 7th ed. Philadelphia; W.B. Saunders: 1985; p. 201-7.

24. Bodrumlu $E$, Sümer $A P$, Sümer $M$, Köprülü $H$. Ondokuz Mayıs Üniversitesi Dişhekimliği Fakültesine başvuran bireylerde dental korkunun değerlendirilmesi. Hacettepe Üni Diş Hek Fak Derg 2006; 1: 51-6.

25. Peretz B, Efrat J. Dental anxiety among young adolescent patients in Israel. Int J Paediatr Dent 2000; 10: 126-32.

26. Henning Abrahamsson K, Berggren U, Carlsson SG. Psychosocial aspects of dental and general fears in dental phobic patients Acta Odontol Scand 2000; 58: 37-43.

27. Mellor A. Dental anxiety and attendance in the north-west of England. J Dent 1992; 20: 207-10.

28. Taani D. Dental fear among a young adult Saudian population. Int Dent J 2001; 51: 62-6.

29. Al-Omari WM, Al-Omiri MK. Dental anxiety among university students and its correlation with their field of study. J Appl Oral Sci 2009; 17: 199-203.

30. Sümer $A P$, Bodrumlu $E$, Sümer $M$, Köprülü $H$. Diş hekimliği öğrencileri ile diş hekimliği dışındaki diğer fakülte öğrencilerinin dental kaygılarının değerlendirilmesi. Turkiye Klinikleri J Dental Sci 2007; 13: 1-5.

\section{Yazışma Adresi}

Dr. Öğretim Üyesi Esra KIZILCI

Erciyes Üniversitesi

Diş Hekimliği Fakültesi

Pedodonti Anabilim Dalı,

Kayseri

TIf: (0352) $2076600-29263$

e-mail: esra_ayhan85@hotmail.com 